\title{
RECENT CHANGES IN AGRICULTURAL LAND OWNERSHIP AND TRANSACTION STRUCTURE IN LATVIA
}

\author{
Visvaldis Valtenbergs ${ }^{1}$, Dr. sc. pol.; Zanita Avotniece ${ }^{2}$, M.geogr.; Ilona Beizitere ${ }^{3}$, M.eoc.; \\ Inese Grumolte-Lerhe ${ }^{4}$, Dr. Sc.pol. \\ ${ }^{1,4}$ University of Latvia, Saeima Analytical Service; ${ }^{2}$ Saeima Analytical Service; ${ }^{3}$ Riga University of Business, Arts \\ and Technology, Saeima Analytical Service
}

\begin{abstract}
Land grabbing, characterised by the amassing of large amounts of land property in the hands of a few landowners, is a topical problem throughout the world. This study characterises the ownership and market situation of agricultural land in Latvia from 2012 till 2017. In 2014, the Law "On Land Privatisation in Rural Areas" was amended establishing various restrictions for natural and legal persons to purchase agricultural land. The effects of these amendments varied in each group of agricultural land market players. The study analyses the structure of agricultural land ownership in Latvia, agricultural land sale and purchase transactions in Latvia and the dynamics of transactions based on data obtained from State Land Service. The results of the study demonstrate that the structure of agricultural land ownership shows indications of property concentration. The proportion of legal entities as owners is significantly increasing, as is the amount of agricultural land they own and the number of purchases they have made. It has been found that properties containing large areas of agricultural land are owned by legal entities with foreign capital. In turn, there is only a small proportion of natural persons of foreign citizenship (hereinafter referred to as "foreign citizens") within the overall agricultural land owner structure.
\end{abstract}

Key words: agricultural land, agricultural land market, agricultural land ownership.

JEL code: Q15, R52

\section{Introduction}

Issues pertaining to land and water resource accessibility are continuously on the global agenda. They are raised in discussions in various contexts regarding such global challenges as food safety and threats to sustainable development. These threats arise not only from the insufficiency of relevant resources, but also the efficiency of their use. In this context, both in relation to land and other natural resources, various labels are being employed, overall indicating that these natural resources are being accumulated by certain entities in such quantities that can be viewed as disproportionate and dangerous, such as land grabbing, land speculation, and land concentration. It must be noted that by no means does land grabbing imply illegal conduct. Favourable conditions may arise out of existing regulations or due to deficiencies therein. Within Europe, land grabbing is an especially widespread phenomenon in Central and Eastern Europe, in regions with fertile soil (Constantin C. et al., 2017; Haerlin B. \& Fuchloch S., 2016).

Studies show that land grabbing has intensified in recent years in the European Union in general and the new Member States in particular (Constantin C. et al., 2017; Kay S. et al., 2015). An obvious consequence of land grabbing and other land related economic and social changes is land concentration, meaning that a small number of farms control a large amount of agricultural land. European level surveys have found that $3 \%$ of large agricultural land owners (more than 100 ha) own $52 \%$ of the total agricultural land area, whereas $75 \%$ of small agricultural land owners (less than 10 ha) own only $11 \%$ of the available agricultural land (TNI, 2016). The large farms have expanded in the European Union at the expense of small farmers (DG IP, 2015; Eurostat, 2011), and these trends not only facilitate the degradation of the land and environment, but have an adverse effect on European food safety and local food culture as well. In Europe, traditional farming practices are being replaced by the intensive agriculture methods of large corporations (UN FAO, 2011; DG IP, 2015). Globally, the phenomenon of land grabbing gained the spotlight in 
2007 - 2008 due to the steep increase in food prices at the time. However, land grabbing remains a cause for concern, including in the European Union (DG IP, 2015). A study on the regulation of land markets in Europe recommends that Eastern European countries find a balance between a highly liberal and protectionist approach (Swinnen J. et al., 2016). Recognizing the strategic importance of the land resource, the European Parliament has also highlighted the need to look at the agricultural land market more broadly than in the framework for the free movement of goods, services, capital and people.

After the abolition of moratorium on the purchase of land by foreign buyers, several new Member States of the European Union, including, Latvia has also introduced restrictions on the purchase of agricultural land by imposing different requirements on the buyer and seller of land (Ciaian P. et al., 2012). In addition, in 2014, amendments to the Law "On Land Privatization in Rural Areas" (hereinafter referred to as "Law") were introduced, which provided for a series of restrictions on the purchase of agricultural land by natural and legal persons (Law On Land..., 1992). Among these restrictions were the introduction of professional qualifications in agriculture and language proficiency tests for the foreign land buyers beyond the certain threshold, and others. In 2015 The Land Fund was established with the main aim of monitoring agricultural land transactions for areas above the threshold stipulated in the Law. It also acquired pre-emptive rights to agricultural land.

Therefore the purpose of this study is to characterize the ownership structure of agricultural land and changes in trading transactions in Latvia during the period from 2012 to 2017 in order to detect the most recent tendencies and the impact of the agricultural land regulation. The study takes innovative approach by examing the role of the foreign capital in agricultural land purchases, by gathering data about the owners of legal entities with domestic and foreign capital.

\section{Data and methodology}

The information used for the purposes of characterising the agricultural land market and changes therein from 2012 to 2017 has been obtained from the State Land Service (hereinafter referred to as SLS). The SLS National Real Estate Cadastre Information System provided information about land parcels containing agricultural land, their owners, that is, natural persons (with an indication "citizen of Latvia", "non-citizen of Latvia", "stateless person of Latvia" or "foreign citizen") or legal entities, as well as the total amount of agricultural land owned and the location of each property.

In order to characterise purchase and sale transactions with land parcels containing agricultural land, information on completed transactions was obtained, adhering to the same criteria, from the SLS Real Estate Market Information Data Base for the period from 1 January 2012 until 31 December 2016. For the purposes of this study, the selection of agricultural land properties and transactions was based on the following criteria:

- land parcels where the land use is agricultural land (arable land, fields, pastures and orchards);

- land parcel has a status of "real estate";

- land parcel is owned by a natural person or legal entity;

- land parcel is not divided into apartment properties.

In order to identify the presence of foreign capital within the fixed capital of legal entities which have concluded sale or purchase transactions involving agricultural land, information was 
requested from "Lursoft IT", Ltd. regarding the proportion of capital contributions by shareholders of legal entities and the citizenship of the shareholders, requesting additional detailed information on some companies.

Research results are based on a research report prepared by the Analytical Service of Saeima of Republic of Latvia "Trading Restrictions of Agricultural Land in Europe and the Situation in Agricultural Land Market in Latvia" (Grumolte-Lerhe I. et al., 2017).

\section{Results and discussion}

\section{Agricultural land and ownership structure in Latvia over the period $2012-2017$}

Agricultural land ownership structure in Latvia has undergone major changes between 2012 and 2017 (Table 1). Although the total area of agricultural land owned by legal entities and natural persons has decreased over this period, the total number of agricultural properties has increased, which is remarkable given the shrinking ownership. Such a trend is indicative of increasing consolidation of agricultural land and property. Another manifestation of this trend is the rising number of agricultural properties and areas registered to a single owner, which has been observed over the same period. In 2017, the average agricultural land area owned by a single entity was 8.71 hectares; natural persons owned areas well below this average, whereas legal entities owned on average around 60 hectares of agricultural land. Most natural persons owned up to two agricultural properties, whereas legal entities owned about eight properties on average.

\section{Changes in agricultural land property ownership in Latvia over the period 2012-2017}

\begin{tabular}{|l|c|c|c|c|c|c|}
\hline \multicolumn{1}{|c|}{$\begin{array}{c}\text { Agricultural land ownership } \\
\text { characteristics }\end{array}$} & $\mathbf{2 0 1 2}$ & $\mathbf{2 0 1 3}$ & $\mathbf{2 0 1 4}$ & $\mathbf{2 0 1 5}$ & $\mathbf{2 0 1 6}$ & $\mathbf{2 0 1 7}$ \\
\cline { 2 - 6 } & & & & & & \\
\hline $\begin{array}{l}\text { Average area of agricultural } \\
\text { land owned by a single entity } \\
\text { (ha) }\end{array}$ & 8.67 & 8.72 & 8.73 & 8.74 & 8.72 & 8.71 \\
\hline $\begin{array}{l}\text { Average number of agricultural } \\
\text { land properties owned by a } \\
\text { single entity }\end{array}$ & 2.0 & 2.0 & 2.0 & 2.1 & 2.1 & 2.1 \\
\hline $\begin{array}{l}\text { Total number of agricultural } \\
\text { land owners }\end{array}$ & 242980 & 242683 & 242363 & 242200 & 242364 & 241920 \\
\hline $\begin{array}{l}\text { Total number of agricultural } \\
\text { land properties }\end{array}$ & 485941 & 492782 & 496195 & 498963 & 500875 & 501972 \\
\hline $\begin{array}{l}\text { Total area of agricultural land } \\
\text { properties owned by different } \\
\text { entities (ha) }\end{array}$ & 2107981 & 2115936 & 2115688 & 2117409 & 2114424 & 2106196 \\
\hline
\end{tabular}

The number of agricultural properties and the area of agricultural land owned by natural persons, including citizens of Latvia, non-citizens of Latvia and the stateless persons of Latvia, has decreased since 2012, and so has the number of such owners. However, the share of foreignowned agricultural land registered to citizens of other countries has increased.

The biggest increase was in the share of legal entities, with such owners holding around 20000 more agricultural land properties and about 140000 ha more of all agricultural land in comparison to 2012. So, looking at the agricultural land ownership structure in 2017, we can clearly see that a relatively small number of owners - legal entities - owned almost a quarter of all available agricultural land (Figure 1). 
Number of owners

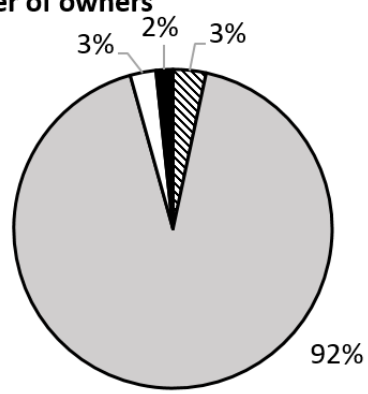

Property size

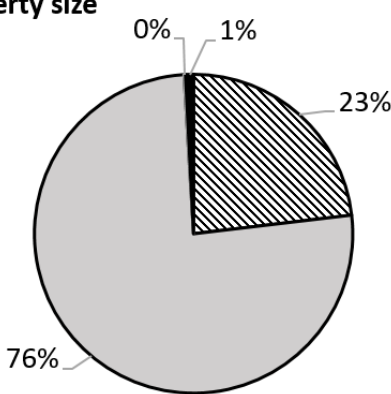

Number of properties

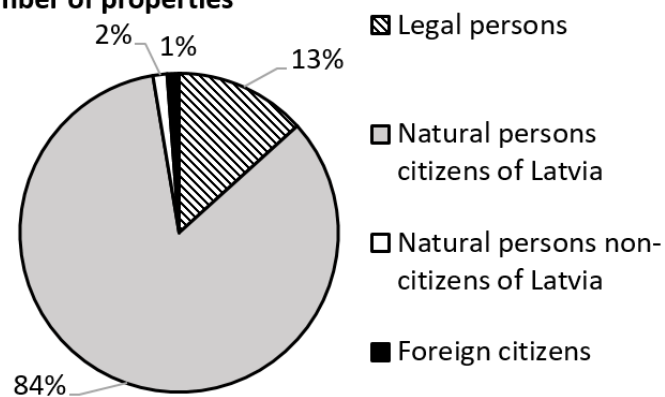

Source: authors' calculations based on the research results Fig. 1. Agricultural land ownership structure in Latvia as of 1 January 2017

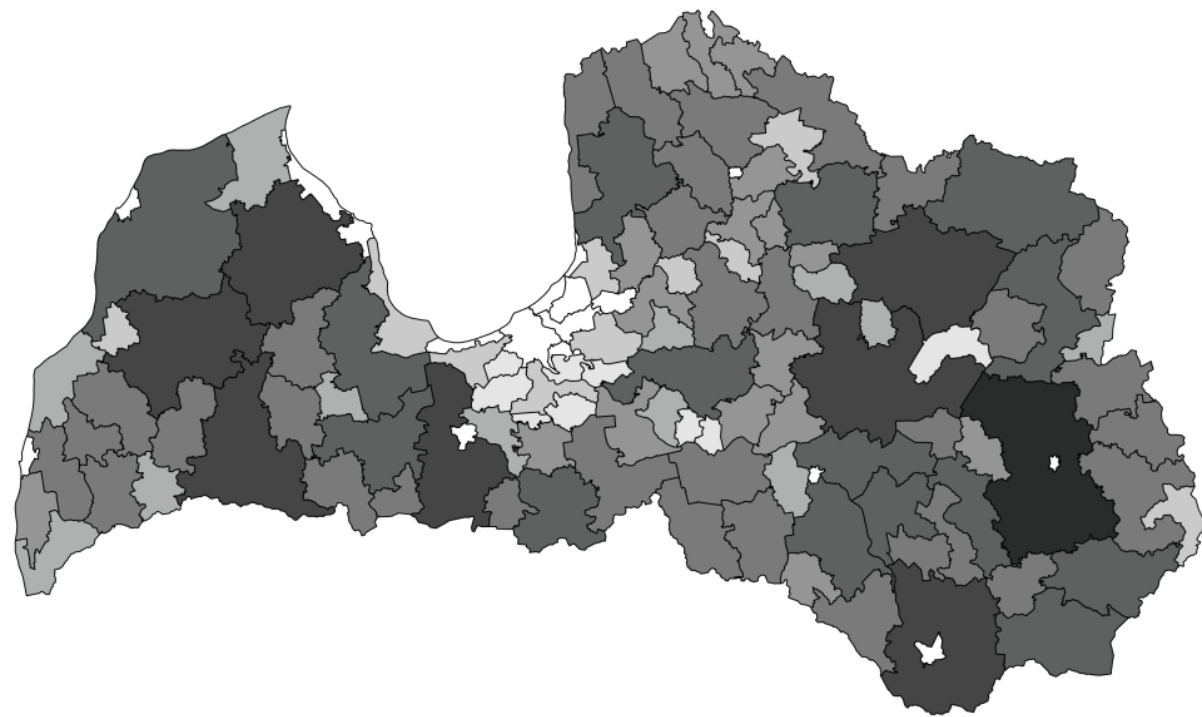

Natural persons citizens of Latvia

$0-2000$

$2000-4000$

$4000-6000$

$6000-8000$

$8000-10000$

$10000-20000$

$20000-40000$

$40000-60000$

$60000-80000$

Legal persons

Source: authors' calculations based on the research results

Fig. 2. Regional breakdown of agricultural land area (ha) owned by natural persons-citizens of Latvia and legal entities as of 1 January 2017 
As of 1 January 2017, most of agricultural land across all regions of Latvia were owned by citizens of Latvia, but large areas of agricultural land, especially in Kurzeme and the Eastern part of Latvia, were owned by legal entities (Figure 2). Foreign citizens, non-citizens of Latvia and the stateless persons of Latvia owned rather small areas of agricultural land, that is, no more than 750 ha in one district, meaning that there is no pronounced regional concentration. At the same time, the total value of agricultural land, in terms of hectares of land owned by one entity in one region, does not determine the impact of the entity on agricultural activities and resource production in the region. For example, Riga has a rather small area of agricultural land, but most of it is owned by legal entities.

\section{Agricultural land transactions in Latvia 2012-2016}

In 2012-2016, there were 5158 legal persons and 28699 natural persons identified as unique buyers of agricultural land. It was established that several buyers had acted as a party to several transactions, just as several land properties had been sold and purchased on more than one occasion. Citizens of Latvia accounted for the majority of the agricultural land buyers, that is, $74 \%$. The second largest group of buyers - $19.3 \%$ - were legal persons with domestic capital. Likewise, in terms of the number of transactions, citizens of Latvia were the most active market participants, accounting for $53 \%$ of total agricultural land transactions and $53.7 \%$ of purchases of all land properties containing agricultural land. Legal persons with domestic capital constituted $36.4 \%$ of total transactions and $35.4 \%$ agricultural land property purchases.

Table 2 summarises the agricultural land transactions 2012-2016 by categories of buyers and sellers. The percentage of the purchased agricultural land (of the total purchased agricultural land in that year) has diminished in all categories, except for purchases by legal persons with domestic capital, which gradually increased and reached $59.73 \%$ in 2016. It must be noted that, in 2015, a considerable increase of transactions as percentage of total was observed among natural persons who are citizens of Latvia, reaching $58.07 \%$. The second largest group of buyers in terms of the number of transactions - legal persons with domestic capital - shows a slight decrease in activity since 2014.

General trends suggest that in the natural person market segment the total purchased agricultural land area has decreased since 2014. At the same time, in the small segments of foreign citizens and non-citizens of Latvia, both the number of buyers and number of agricultural land properties has also decreased since 2014. The relatively small percentage of buyers and transactions in the agricultural land market coupled with the small amount of the purchased agricultural land could indicate that the non-citizens of Latvia and foreign citizens are not buying agricultural land primarily for agricultural use. The results of the research confirm the conclusions of the State Land Service survey (SLS, 2016, 10) about the overall reduction of market activity by some 20-30\% since the coming into effect of the amendments to the Law in 2014.

A comparison of performance in the natural person and legal person market segments shows that legal persons with domestic capital dominated the purchase side of the market, and, accordingly, constitute the largest group of agricultural land buyers during the period in question. The second largest group - citizens of Latvia - has been quite active in terms of both the number of transactions and the number of the purchased agricultural land properties. However, it must be noted that the area of the purchased agricultural land was mainly small. 


\section{Purchased and sold agricultural land areas and transactions by categories of buyers and sellers ( $\%$ of total transactions) in Latvia over the period 2012-2016}

\begin{tabular}{|c|c|c|c|c|c|c|}
\hline \multicolumn{2}{|c|}{ Buyers and sellers by categories } & 2012 & 2013 & 2014 & 2015 & 2016 \\
\hline \multicolumn{7}{|c|}{ Purchased agricultural land as percentage of total transactions } \\
\hline \multirow{3}{*}{ Natural persons } & Citizens of Latvia & 31.35 & 32.12 & 30.21 & 31.62 & 30.18 \\
\hline & Foreign citizens & 0.16 & 0.20 & 0.61 & 0.80 & 0.50 \\
\hline & Non-citizens of Latvia & 0.19 & 0.07 & 0.04 & 0.03 & 0.02 \\
\hline \multirow{2}{*}{ Legal persons } & Domestic capital & 52.56 & 54.08 & 54.95 & 57.34 & 59.73 \\
\hline & Foreign capital & 15.74 & 13.54 & 14.19 & 10.21 & 9.57 \\
\hline \multicolumn{7}{|c|}{ Sold agricultural land as percentage of total transactions } \\
\hline \multirow{3}{*}{ Natural persons } & Citizens of Latvia & 71.86 & 75.27 & 69.82 & 76.44 & 74.15 \\
\hline & Foreign citizens & 1.21 & 1.45 & 1.17 & 0.80 & 0.83 \\
\hline & Non-citizens of Latvia & 0.29 & 0.17 & 0.24 & 0.17 & 0.33 \\
\hline \multirow{2}{*}{ Legal persons } & Domestic capital & 18.37 & 15.46 & 19.58 & 17.11 & 17.58 \\
\hline & Foreign capital & 8.27 & 7.64 & 9.19 & 5.49 & 7.11 \\
\hline \multicolumn{7}{|c|}{ Agricultural land purchasing transactions as percentage of total transactions } \\
\hline \multirow{3}{*}{ Natural persons } & Citizens of Latvia & 48.37 & 51.09 & 51.11 & 58.07 & 57.42 \\
\hline & Foreign citizens & 1.13 & 1.76 & 2.05 & 1.02 & 1.11 \\
\hline & Non-citizens of Latvia & 1.42 & 1.16 & 1.04 & 0.67 & 0.48 \\
\hline \multirow{2}{*}{ Legal persons } & Domestic capital & 39.53 & 37.78 & 36.78 & 33.21 & 33.97 \\
\hline & Foreign capital & 9.55 & 8.21 & 9.02 & 7.04 & 7.02 \\
\hline \multicolumn{7}{|c|}{ Agricultural land selling transactions as percentage of total transactions } \\
\hline \multirow{3}{*}{ Natural persons } & Citizens of Latvia & 78.55 & 78.33 & 74.41 & 76.78 & 77.46 \\
\hline & Foreign citizens & 1.06 & 1.30 & 1.19 & 1.12 & 1.29 \\
\hline & Non-citizens of Latvia & 1.49 & 1.17 & 1.11 & 1.35 & 1.44 \\
\hline \multirow{2}{*}{ Legal persons } & Domestic capital & 14.96 & 14.98 & 16.41 & 15.70 & 14.54 \\
\hline & Foreign capital & 3.93 & 4.22 & 6.88 & 5.05 & 5.27 \\
\hline
\end{tabular}

Source: authors' calculations based on the research results

The selling side of the market was dominated by natural persons who are citizens of Latvia. They accounted for $81.7 \%$ of all sold agricultural land, $77.1 \%$ of transactions, $75.6 \%$ of all land properties containing agricultural land, and $73.3 \%$ of the total area of the sold agricultural land. It must be pointed out that, among the sellers, it was the legal persons with domestic capital that sold less agricultural land than they purchased.

The most active regions of Latvia in terms of the number of agricultural land transactions during the time period in question were as follows: Rezekne, Daugavpils, Jelgava, Talsi, Madona, and Limbazi. In terms of the area of the purchased agricultural land, as well as in terms of the number of transactions, the leading regions are as follows: Rezekne, Daugavpils, Jelgava, Talsi, and Madona (Figure 3). It must be noted that in there are many instances of a single land property changing hands on several occasions. For instance, two agricultural land properties have been sold 10 and 11 times respectively during the time period in question. 


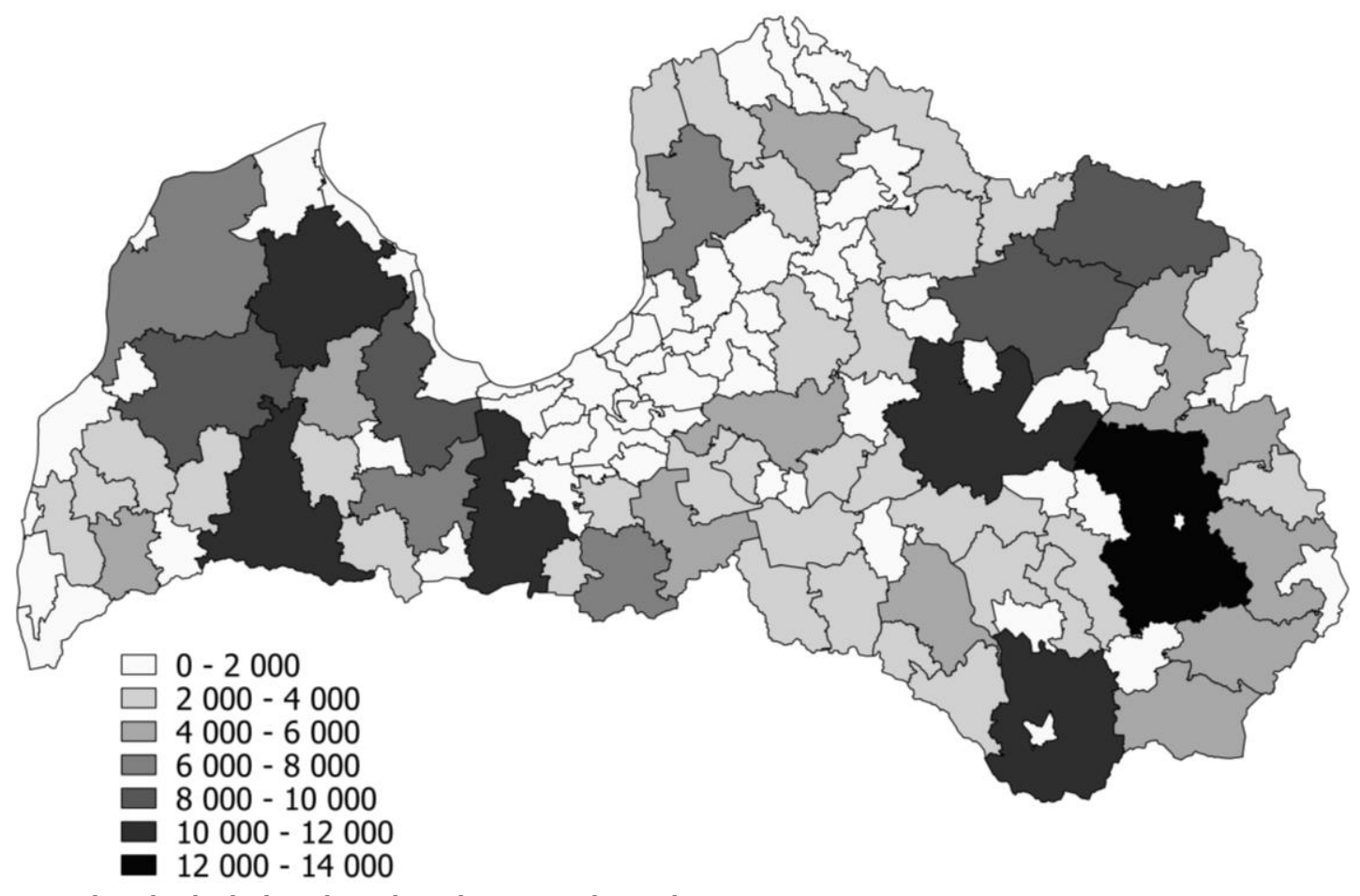

Source: authors' calculations based on the research results

Fig. 3. Regional breakdown of total purchased agricultural land area (ha) over the period 2012-2016 in Latvia

\section{Conclusions}

1) In the time period between 2012 and 2017, the agricultural land market has displayed signs of consolidation:

- The dominance of legal persons in the agricultural land market has grown considerably in terms of both the owned area and the number of purchase transactions. Concerning the agricultural land ownership in 2017, it must be pointed out that a relatively small number of legal persons ( $3 \%$ ) own almost a quarter ( $23 \%$ ) of the available agricultural land.

- At the same time, such natural entities as citizens of Latvia, non-citizens of Latvia, and the stateless persons of Latvia are not only losing the area and number of agricultural land plots, but are also decreasing in ownership numbers. The proportion of foreign citizens in terms of agricultural land ownership remains low. It applies also to the area of agricultural land, and the number of transactions.

2) Legal persons with domestic capital dominated the purchase side of the agricultural land market during the time period in question. The second largest group - citizens of Latvia - was quite active in terms of both the number of transactions and the number of purchased agricultural land properties; however, it must be noted that the area of the purchased agricultural land was mainly small. Also, legal persons with foreign capital have had a substantial impact on the agricultural land market.

3) An analysis of dynamics of the sales and purchases of agricultural land over the time period in question shows that natural persons citizens of Latvia sold much more property than they bought. 
4) The agricultural land purchase restrictions adopted in 2014 have lowered the market activity in terms of sold land area and the number of transactions, the only exception being legal persons with domestic capital; the area of agricultural land purchased by them has steadily grown.

5) However, the research does not confirm the thesis that the agricultural land of Latvia is being sold off to foreign citizens, since their ownership in terms of land area and remains relatively low, and so does their involvement in agricultural land transactions.

\section{Bibliography}

1. Ciaian, P. , Kancs, d'Artis, Swinnen, J., Van Herck, K. and Vranken, L. (2012). Sales Market Regulations for Agricultural Land in EU Member States and Candidate Countries. Retrieved: https://www.ceps.eu/publications/sales-market-regulations-agricultural-land-eu-member-states-andcandidate-countries Access: 15.01.2018.

2. Constantin, C., Luminita, C., Vasile, A.J. (2017). Land Grabbing: A Review of Extent and Possible Consequences in Romania. Land Use Policy, Volume 62, pp. 143-150.

3. European Parliament Directorate General for Financial Stability, Financial Services and Capital Markets Union (DG FISMA) (2017). The Regulation of Agricultural Land Sales Markets in the EU. Discussion paper for the meeting to exchange views on the agricultural land sales markets.

4. Eurostat (2011). Large Farm Statistics. Retrieved: http://ec.europa.eu/eurostat/statisticsexplained/index.php/Archive:Large_farm_statistics Access: 02.12.2017.

5. Food and Agriculture Organization of the United Nations (UN FAO) (2011). The State of Food Insecurity in the World. Retrieved: http://www.fao.org/3/a-i4646e.pdf Access: 20.12.2017.

6. Grumolte-Lerhe, I., Avotniece, Z., Beizitere, I., Valtenbergs, V. (2017). Lauksaimnieciba izmantojamas zemes tirdzniecibas ierobezojumi Eiropa un tirgus situacija Latvija (Trading Restrictions of Agricultural Land in Europe and the Situation in Agricultral Land Market in Latvia). Retrieved: http://www.saeima.Iv/petijumi/LIZ_tirdzniecibas_ierobezojumi_24102017.pdf Access 07.02.2018.

7. Haerlin, B., Fuchsloch, S. (2016). Land Rush and the Sellout of Europe's Farmland. Retrieved: http://www.arc2020.eu/land-rush-land-grab/ Access 20.12.2017.

8. Kay, S., Peuch, J., Franco, J. (2015). Extent of Farmland Grabbing in the EU. Retrieved: http://www.europarl.europa.eu/RegData/etudes/STUD/2015/540369/IPOL_STU(2015)540369_EN.pdf Access 13.01.2018.

9. Law On Land Privatization in Rural Areas, Republic of Latvia, 09.07.1992. Retrieved: https://likumi.Iv/ta/en/id/74241-on-land-privatisation-in-rural-areas Access: 08.02.2018.

10.Swinnen, J., Van Herck, K., Vranken, L. (2016). The Diversity of Land Markets and Regulations in Europe, and (Some of) Its Causes. The Journal of Development Studies, Volume 52, Issue 2, pp. 186-205.

11. The State Land Service (SLS). (2016). Nekustama ipasuma tirgus parskats. Lauku zemes tirgus tendences pec 2014. gada regulejuma izmainam. (Real Estate Market Overview. Trends in Agricultural Land Market Following the Amendments of Regulation in 2014). Retrieved: http://www.vzd.gov.Iv/files/nekustama_ipasuma_tirgus_parskats_22_12_2016.pdf Access: 13.01.2018.

12. Transnational Institute (TNI) (2016). Land Grabbing and Land Concentration in Europe. A Research Brief. Retrieved: https://www.tni.org/files/publication-downloads/landgrabbingeurope_a5-2.pdf Access: 15.01.2018. 